\title{
Anatomical Attributes of the Musculus quadriceps femoris Responsible for Poor Crawling Ability in the Greater Horseshoe Bat (Rhinolophus ferrumequinum)
}

\author{
Atributos Anatómicos del Músculo Cuádriceps Femoral Responsable de la Limitada Capacidad \\ de Arrastre en el Murciélago Grande de Herradura (Rhinolophus ferrumequinum)
}

Masayuki Kobayashi ${ }^{1}$

KOBAYASHI, M. Anatomical attributes of the Musculus quadriceps femoris responsible for poor crawling ability in the greater horseshoe bat (Rhinolophus ferrumequinum). Int. J. Morphol., 36(1):69-73, 2018.

SUMMARY: In mammals, the Musculus quadriceps femoris is a well-developed extensor muscle of the thigh. It is also relatively well developed in bats. The muscle group consists of a distally elongated muscle belly, which is important for the full extension of the knee joint during terrestrial locomotion. However, most bats species demonstrate poor terrestrial locomotion, although several species are able to crawl on the ground. Among the crawling bats, knee joint extension is necessary for crawling. Among bat species generally, the $M$. quadriceps femoris has a distally elongated belly for extending the shank, although the feature also occurs among poor crawling bat species. The relationship between a relatively well-developed M. quadriceps femoris and poor crawling ability in bats is incongruous, but there is a possibility that bats with a reduced $M$. quadriceps femoris have not yet been found. The greater horseshoe bat (Rhinolophus ferrumequinum) has long been known to be incapable of crawling, but there are no detailed descriptions in the literature concerning this bat's $M$. quadriceps femoris. The findings of this study reveal that the M. quadriceps femoris of Rh. ferrumequinum has a short muscle belly attached to the proximal portion of the femur; furthermore, the insertional tendon of this muscle and its patellar ligament are very thin. These morphological features suggest that this species cannot exert a strong and long-distance extension of its knee joints, unlike most other bat species. In addition to the above described morphological features, the M. rectus femoris of Rh. ferrumequinum is fused with the vasti in the M. quadriceps femoris. This $M$. quadriceps femoris arises from the pelvis and inserts onto the femur. Therefore, Rh. ferrumequinum has an $M$. quadriceps femoris specialized for flexion of the hip joint.

KEY WORDS: Rhinolophus ferrumequinum; Musculus quadriceps femoris; Patellar ligament.

\section{INTRODUCTION}

Generally, in mammals, the Musculus quadriceps femoris consists of the M. rectus femoris from the ilium and three vasti from the femur (e.g., Romer \& Parsons, 1986). This muscle covers almost all of the anterior and lateral portions of the thigh. The strong tendon inserts onto the base of the patella, and the stout patellar ligament continues to the head of the tibia (Romer \& Parsons). The M. quadriceps femoris is quite well developed and is a very powerful extensor muscle of the shank, which is useful for terrestrial locomotion (Kardong, 2014).

All bats are capable of powered flight using the webbed wings of their forelimbs, but most bats are poor at terrestrial locomotion (Lawrence, 1969), although several bats are able to crawl well on the ground (Dietz, 1973; Riskin et al., 2005, 2006; Schutt \& Simmons, 2006). In fact, crawling bat species (Phyllostomidae: Desmodus rotundus and Diaemus youngi) extend their knee joints in the caudal direction when crawling forward (Altenbach, 1979; Schutt et al., 1999; Riskin et al., 2005). In mammals, generally, the extensor muscles of the knee joint are the M. quadriceps femoris and M. sartorius (Dyce et al., 2002). However, Meckel (1828) pointed out that the M. sartorius is absent in bats, and no one since then has identified the M. sartorius in any descriptions of the hind limb musculature in bats (cf. Humphry, 1869; Macalister, 1872; Vaughan, 1959; Mori, 1960). Therefore, it appears that the only muscle associated with extending the knee joint in bats is the M. quadriceps femoris. Based on the relationship between bat crawling behavior and the development of their M. quadriceps femoris, we could infer that the M. quadriceps femoris should be reduced in bats that demonstrate poor crawling locomotion. 
However, rare crawling bats (e.g., Macrotus californicus, Phyllostomidae) have a relatively large $M$. quadriceps femoris, which they use for extending the shank (Vaughan). Among mammalian orders, bats have the second highest number of species, after Rodentia (cf. Wilson \& Reeder, 2005). Myological information on the M. quadriceps femoris is not available for many bat species, and so there might be some species that have poorly developed $M$. quadriceps femoris that corresponds to their poor crawling locomotion.

The greater horseshoe bat (Rhinolophus ferrumequinum) is widely distributed throughout North Africa and southern Europe through south-west Asia, the Caucasus, Iran, Afghanistan, Pakistan, and the Himalayas to south-eastern China, Korea, and Japan (Csorba et al., 2003; Simmons, 2005). It has long been known that the greater horseshoe bat is unable to walk (Coward, 1908). However, there has been only one study (Macalister) describing the musculature of $R h$. ferrumequinum, and that study did not describe the hind limb musculature in any detail. In addition, no descriptions of hind limb musculature have been carried out in horseshoe bat species other than that of Rh. ferrumequinum. To address this gap in our knowledge, I provide anatomical information about the $M$. quadriceps femoris and describe how this corresponds to the poor crawling ability of Rh. ferrumequinum.

\section{MATERIAL AND METHOD}

This study focuses on the M. quadriceps femoris of $R h$. ferrumequinum, and using osteological and myological terminologies proposed by Vaughan. The specimens investigated are listed in Table I. All specimens were preserved in alcohol (the samples were first cold-stored and then fixed in formalin). Because all examined the bats were small, detailed dissections were performed using a stereo microscope (SHIMADZU STZ-168-TL), and a digital microscope (KEYENCE VHX-1000) was used for taking photos of the $M$. quadriceps femoris tendon and the patellar ligament in Rh. ferrumequinum.
As bats evolved, their legs rotated so that the feet and claws turned backward (Altringham, 2011). Therefore, anatomical terms used for most mammals concerning the positions and directions of legs are not applicable for bats. Given these differences, in the present study, terms typically used to describe the anterior/posterior surface of the thigh in mammals herein instead refer to the extensor/ flexor surface of the thigh.

\section{RESULTS}

Musculus quadriceps femoris (Figs. 1B, 2A, 3A, and 3B). The $M$. quadriceps femoris of Rh. ferrumequinum comprises the $M$. rectus femoris, the $M$. vastus medialis, and the $M$. vastus intermedius. The $M$. rectus femoris is the most developed among the three muscles of $M$. quadriceps femoris. It arises from the cranial portion of the acetabulum and is flat in a dorsoventral direction at its origin. The thin and short M. vastus medialis arises from the medial ridge of the femur, while the weak $M$. vastus intermedius arises from the distal portion of the greater trochanter and the extensor surface of the medial ridge of the femur. The muscle fibers of the $M$. rectus femoris and the $M$. vastus intermedius fuse with each other into one common muscle at the proximal half of $M$. quadriceps femoris, which then changes into a common tendon. The insertion of the M. vastus medialis is approximately extensor-medial to the $M$. rectus femoris and the $M$. vastus intermedius, while the $\mathrm{M}$. vastus medialis is contiguous with the common tendon of the $\mathrm{M}$. rectus femoris and the M. vastus intermedius. Finally, a narrow and thin common tendon of the three muscles inserts onto the proximal end of the patella, and this thin tendon continues to the patellar ligament.

The patellar ligament connects the distal end of the patella to the process-like ridge on the middle of the proximal tibia. The patellar ligament is so thin that the boundary between the ligament and the surrounding connective tissue is unclear.

Table I. The specimens used in this study.

\begin{tabular}{|c|c|c|c|}
\hline Species & $\begin{array}{l}\text { Specimens } \\
\text { Number }\end{array}$ & Donor or Location & Storage of Specimens \\
\hline $\begin{array}{l}\text { Rhinolophus } \\
\text { ferrumequinum }\end{array}$ & OUS-LCA 272 & $\begin{array}{l}\text { Okayama Prefecture, } \\
\text { Japan }\end{array}$ & $\begin{array}{l}\text { Okayama University of Science } \\
\text { (Okayama, Japan) }\end{array}$ \\
\hline $\begin{array}{l}\text { Rhinolophus } \\
\text { ferrumequinum }\end{array}$ & OUS-LCA 291 & $\begin{array}{l}\text { Okayama Prefecture, } \\
\text { Japan }\end{array}$ & $\begin{array}{l}\text { Okayama University of Science } \\
\text { (Okayama, Japan) }\end{array}$ \\
\hline $\begin{array}{l}\text { Rhinolophus } \\
\text { ferrumequinum }\end{array}$ & H16-105 & $\begin{array}{l}\text { Kouchi Prefecture, } \\
\text { Japan }\end{array}$ & $\begin{array}{l}\text { NPO Shikoku Institute of Natural } \\
\text { History (Kouchi, Japan) }\end{array}$ \\
\hline $\begin{array}{l}\text { Rhinolophus } \\
\text { ferrumequinum }\end{array}$ & H16-106 & $\begin{array}{l}\text { Kouchi Prefecture, } \\
\text { Japan }\end{array}$ & $\begin{array}{l}\text { NPO Shikoku In stitute of Natural } \\
\text { History (Kouchi, Japan) }\end{array}$ \\
\hline
\end{tabular}




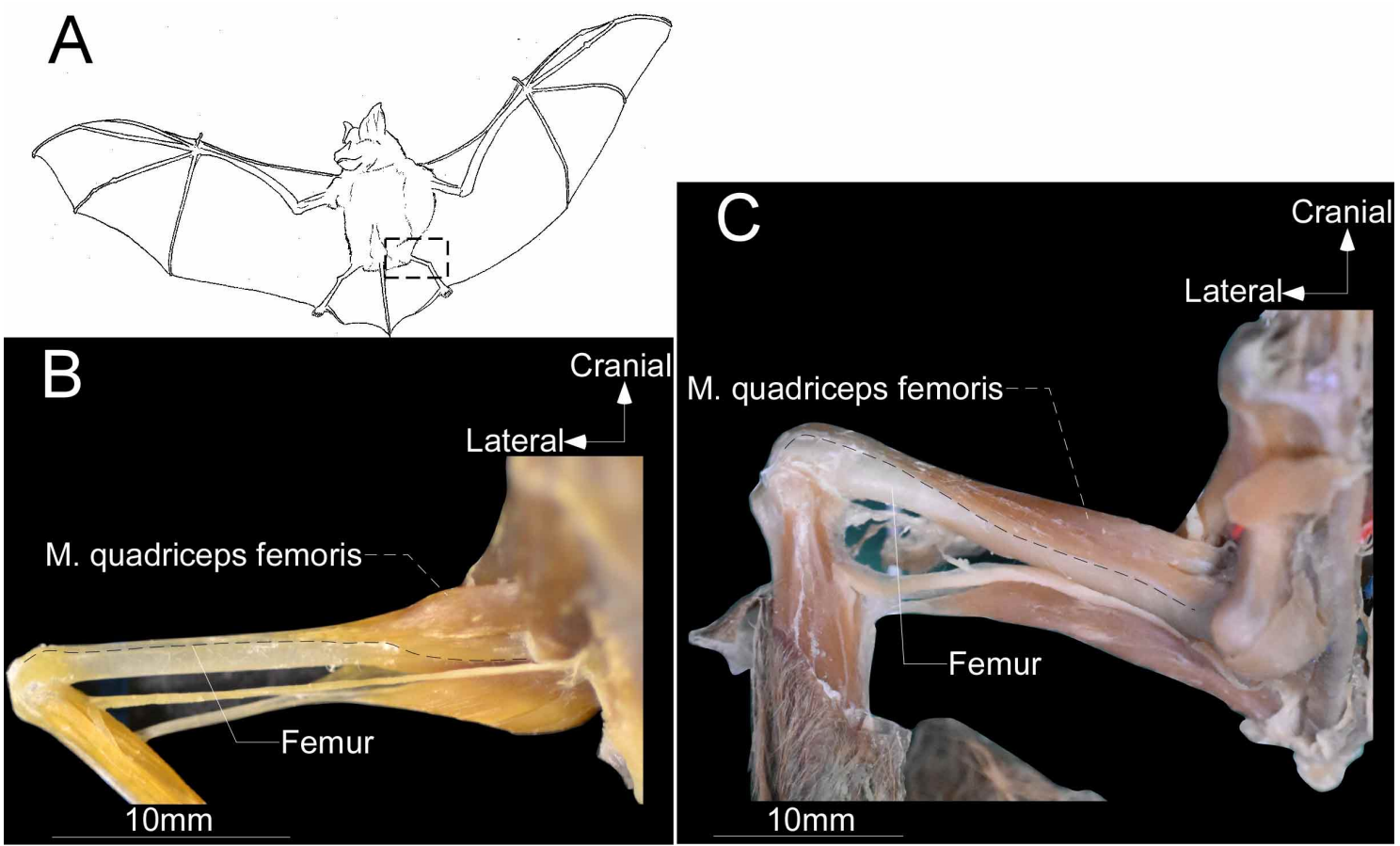

Fig. 1 A) Schematic representation of ventral view of Rhinolophus showing proportions of the body. The dashed square indicates the dissected area of Figs. 1B and C. B) Lateral view of the left hind limb of Rhinolophus ferrumequinum (OUS-LCA 291) showing the I. C) Lateral view of the left hind limb of Rousettus leschenaultii (OUS-LCA 367). The dotted line indicates the boundary between the M. quadriceps and the femur. [Abbreviation: M., musculus].

A
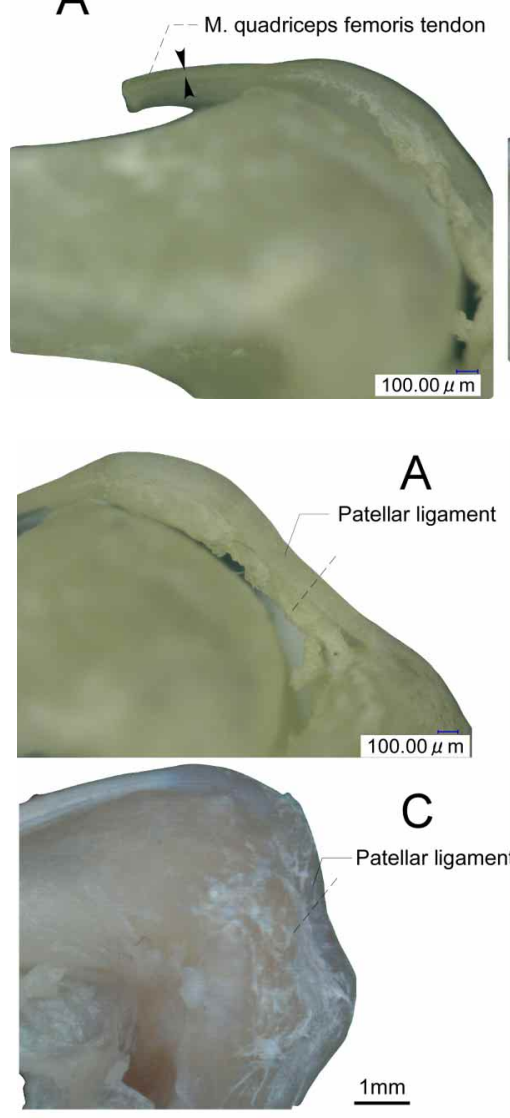

B
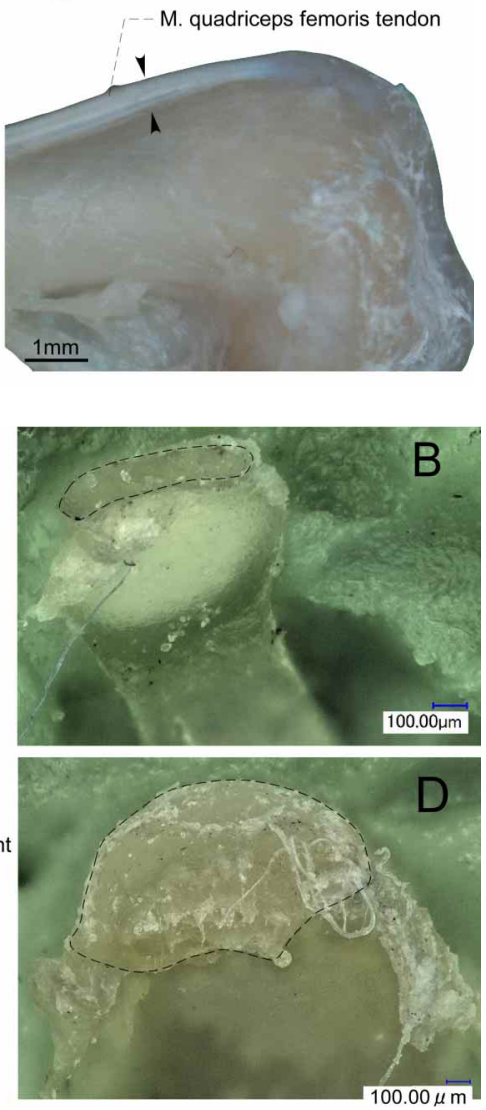

Fig. 2 Medial view of the left knee joint showing the Musculus quadriceps femoris tendon: A) Rhinolophus ferrumequinum (OUS-LCA 291), B) Rousettus leschenaultii (OUS-LCA 367). The distance between the arrow heads indicates the thickness of the $M$. quadriceps femoris tendon. [Abbreviation: M., musculus].

Fig. 3 A) Medial view of the left knee joint of Rhinolophus ferrumequinum (OUS-LCA 291) showing the patellar ligament. B) Cross section of the patellar ligament of Rh. ferrumequinum (OUS-LCA 291) at the broken line in Fig. 3A. C) Medial view of the left knee joint of Rousettus leschenaultii (OUS-LCA 367) showing the patellar ligament. D) Cross section of the patellar ligament of Ro. leschenaultii (OUS-LCA 365) at the broken line in Fig. 3C. The dashed line in Figures $\mathrm{C}$ and $\mathrm{D}$ indicates the cross section position of the patellar ligament. 
Musculus Sartorius. Both the M. quadriceps femoris and the M. sartorius are extensor muscles of the thigh in mammals (Dyce et al.), but bats are not known to possess an M. sartorius (Humphry; Macalister; Vaughan; Mori). This muscle also was not found in any of the specimens dissected in the present study.

\section{DISCUSSION}

Based on previous studies, the $M$. quadriceps femoris in most bats has a distally extended muscle belly like other mammals (cf. Humphry; Macalister; Howell \& Straus, 1933; Vaughan; Mori; Crouch, 1969; Young, 1975; Evans \& De Lahunta, 2013; Standring, 2016) (refer to Rousettus leschenaultii of Fig. 1C). However, Rh. ferrumequinum is the exception in that its muscle belly is short. The contraction distance is longer for a muscle with a long belly than a muscle with a short belly, because the muscle belly is the part of the muscle that contracts (Kardong). Therefore, a distally elongated muscle belly of the M. quadriceps femoris (common to almost all bats) enables bats to fully extend their knee joints. In contrast, the short muscle belly of $M$. quadriceps femoris in Rh. ferrumequinum prevents it from fully extending the knee joint.

Generally, in mammals including bats (cf. Humphry; Macalister; Howell \& Straus; Vaughan; Mori; Crouch; Young; Smith et al., 1995; Evans \& De Lahunta; Standring), the insertional tendon of the M. quadriceps femoris and the patellar ligament were developed fully enough to contain the patella (refer to Ro. leschenaultii of Figs. 2B, 3C and 3D). The tendon and ligament are stout enough to allow the M. quadriceps femoris to transmit a large amount of power to the tibia. However, in Rh. ferrumequinum, the patellar ligament and the insertional tendon of the M. quadriceps femoris are very thin and weak, are thin where they cover the patella and are much thinner and weaker than generally observed in mammals. These morphological features of the M. quadriceps femoris (thin and weak tendon and patellar ligament and its short muscle belly) suggest that $R h$. ferrumequinum is unable to fully and powerfully extend its shank.

The M. quadriceps femoris in mammals are separated into four muscles; in contrast, the $M$. rectus femoris of $R h$. ferrumequinum does fuse with the vasti, which then attach onto the extensor surface of the femur. In other words, the M. quadriceps femoris in Rh. ferrumequinum appears to be a hip-joint muscle arising from the pelvis and inserting onto the femur. Furthermore, in Rh. ferrumequinum, the muscle belly of the vasti is assembled on the proximal region of the extensor surface of the femur, resulting in the rectus femoris having an insertional position at the proximal point of rotation of the hip joint. This feature suggests that the $M$. quadriceps femoris of Rh. ferrumequinum enables the femur to fully flex the femur. This can occur because the muscle insertion at the proximal point of the rotation (at the joint) enables the distal end to rotate more completely (Kardong).

Evolutionarily, Rh. ferrumequinum lineage lost its capacity to crawl. It is difficult for this species to crawl, because its M. quadriceps femoris has a short muscle belly, a thin insertional tendon, and a thin and weak patellar ligament. This prevents extension of the knee joint, which plays an important role in crawling for bats. However, because the muscle belly of $M$. quadriceps femoris is almost attached to the proximal area of the femur (through the vasti), its main function now is flexion of the hip joint, rather than extension of the knee joint. Based on these findings, it appears that the M. quadriceps femoris of Rh. ferrumequinum has unique morphological attributes that make it unsuitable to allow efficient crawling locomotion.

\section{ACKNOWLEDGMENTS}

I would like to thank Prof. Masahito Natori of the Okayama University of Science for thoughtful comments and suggestions to improve the manuscript. I would also like to thank Dr. Shuji Yachimori of the NPO Shikoku Institute of Natural History for granting permission to examine the materials used in this study, Rhinolophus ferrumequinum and for giving helpful comments, and acknowledge the Hiroshima-City Asa Zoological Park and the Ikeda Zoo for granting permission to examine the specimens, Rousettus leschenaultii (OUS-LCA 365 and OUS-LCA 367).

KOBAYASHI, M. Atributos anatómicos del músculo cuádriceps femoral responsable de la limitada capacidad de arrastre en el murciélago grande de herradura (Rhinolophus ferrumequinum). Int. J. Morphol., 36(1):69-73, 2018.

RESUMEN: En los mamíferos, el Musculus quadriceps femoris es un músculo extensor bien desarrollado del muslo. Este músculo también está relativamente bien desarrollado en murciélagos. El grupo muscular consiste en un vientre muscular distalmente alargado, lo que es importante para la extensión completa de la articulación de la rodilla durante la locomoción terrestre. Sin embargo, la mayoría de las especies de murciélagos muestran limitada locomoción terrestre, aunque varias especies pueden arrastrarse por el suelo. Entre los murciélagos reptantes, la exten- 
sión de la articulación de la rodilla es necesaria para gatear. Entre las especies de murciélagos en general, el M. quadriceps femoris tiene un vientre distalmente alargado para extender la rodilla, aunque la característica también ocurre entre las especies de murciélagos de rastreo limitado. La relación entre un M. quadriceps femoris relativamente bien desarrollado y la escasa capacidad de rastreo en los murciélagos es incongruente, pero existe la posibilidad de que aún no se hayan encontrado murciélagos con M. cuádriceps femoral poco desarrollado. Se sabe desde hace tiempo que el murciélago de herradura (Rhinolophus ferrumequinum) es incapaz de gatear, pero no hay descripciones detalladas en la literatura sobre el M. quadriceps femoris de este murciélago. Los hallazgos de este estudio revelan que el $M$. quadriceps femoris de Rh.ferrumequinum tiene un vientre muscular corto, unido a la epífisis proximal del fémur; además, el tendón de inserción de este músculo y su ligamento patelar son muy delgados. Estas características morfológicas sugieren que esta especie no puede ejercer una extensión importante y de larga distancia de la articulación de la rodilla, a diferencia de la mayoría de otras especies de murciélagos. Además de las características morfológicas descritas anteriormente, el $M$. rectus femoris de Rh. ferrumequinum está fusionadocon el vasto del $M$. quadriceps femoris. El M. quadriceps femoris se origina de la pelvis y se inserta en el fémur. Por lo tanto, Rh. ferrumequinum tiene un $M$. quadriceps femoris especializado para la flexión de la articulación de la cadera.

PALABRAS CLAVE: Rhinolophus ferrumequinum; Musculus quadriceps femoris; Ligamento patelar.

\section{REFERENCES}

Altenbach, J. S. Locomotor Morphology of the Vampire Bat, Desmodus rotundus. Cambridge, The American Society of Mammalogists, Special Publication No. 6, 1979.

Altringham, J. D. Bats from Evolution to Conservation. $2^{\text {nd }}$ ed. New York, Oxford University Press, 2011.

Coward, T. A. XI. Notes on the Greater horseshoe bat, Rhinolophus ferrumequinum (Schreber), in captivity. Mem. Proc. Manch. Lit. Philos. Soc., 52(11):1-12, 1908.

Crouch, J. E. Text-Atlas of Cat Anatomy. Philadelphia, Lea \& Febiger, 1969.

Csorba, G.; Ujhelyi, P. \& Thomas, N. Horseshoe Bats of the World (Chiroptera: Rhinolophidae). Shropshire, Alana Books, 2003.

Dietz, C. L. Bat walking behavior. J. Mammal., 54(3):790-2, 1973.

Dyce, K. M.; Sach, W. O. \& Wensing, C. J. G. Text Book of Veterinary Anatomy. $3^{\text {rd }}$ ed. Philadelphia, Saunders, 2002.

Evans, H. E. \& De Lahunta, A. Miller's Anatomy of the Dog. $4^{\text {th }}$ ed. Philadelphia, Saunders, 2013.

Howell, A. B. \& Straus Jr., W. L. The Muscular System. In: Hartman, C. G. \& Straus, Jr. W. L. (Eds.). The Anatomy of the Rhesus monkey (Macaca mulatta). Baltimore, The Williams \& Wilkins Company, 1933. pp.89175.

Humphry. The myology of the limbs of Pteropus. J. Anat. Physiol., 3(Pt. 2):294-491, 1869.

Kardong, K. V. Vertebrates: Comparative Anatomy, Function, Evolution. $7^{\text {th }}$ ed. New York, McGraw-Hill Companies, 2014.

Lawrence, M. J. Some observations on non-volant locomotion in Vespertilionid bats. J. Zool. (Lond.), 157(3):309-17, 1969.

Macalister, A. The myology of the cheiroptera. Philos. Trans. R. Soc. Lond., 162:125-71, 1872.
Mori, M. Muskulatur des Pteropus edulis. Okajimas Folia Anat. Jpn., 36:253-307, 1960.

Riskin, D. K.; Bertram, J. E. \& Hermanson, J. W. Testing the hindlimbstrength hypothesis: non-aerial locomotion by Chiroptera is not constrained by the dimensions of the femur or tibia. J. Exp. Biol., 208(Pt. 7):1309-19, 2005.

Riskin, D. K.; Parsons, S.; Schutt, W. A. Jr.; Carter, G. G. \& Hermanson, J. W. Terrestrial locomotion of the New Zealand short-tailed bat Mystacina tuberculata and the common vampire bat Desmodus rotundus. J. Exp. Biol., 209(Pt. 9):1725-36, 2006.

Romer, A. S. \& Parsons, T. S. The Vertebrate Body. 6th ed. Philadelphia, Saunders College Publishing, 1986.

Schutt Jr., W. A. \& Simmons, N. B. Quadrupedal Bats: Form, Function, and Evolution. In: Zubaud, A.; Mccracken, G. F. \& Kunz, T. H. (Eds.). Functional and Evolutionary Ecology of Bats. New York, Oxford University Press, 2006. pp.145-59.

Schutt, W. A. Jr.; Muradai, F.; Mondol, N.; Joseph, K. \& Brockmann, K. B. Behavior and maintenance of captive white-winged vampire bats, Diaemus youngi. J. Mammal., 80(1):71-81, 1999.

Simmons, N. B. Order Chiroptera. In: Wilson, D. E. \& Reeder, D. M. (Eds.). Mammal species of the World: taxonomic and geographical reference. Baltimore, Johns Hopkins University Press, 2005. pp.312-529.

Smith, B. J.; Holladay, S. D. \& Smith, S. A. Patella of selected bats: patterns of occurrence or absence and associated modifications of the quadriceps femoris tendon. Anat. Rec., 242(4):575-80, 1995.

Standring, S. Gray's Anatomy: The Anatomical Basis of Clinical Practice. $41^{\text {st }}$ ed. Amsterdam, Elsevier Health Sciences, 2016

Vaughan, T. A. Functional morphology of three bats: Eumpos, Myotis, Macrotus. Univ. Kans. Publ. Mus. Nat. Hist., 12:1-153, 1959.

Wilson, D. E. \& Reeder, D. M. Mammalian Species of the World: A Taxonomic and Geographic Reference. $3^{\text {rd }}$ ed. Baltimore, The Johns Hopkins University Press, 2005.

Young, J. Z. The Life of Mammals: Their Anatomy and Physiology. $2^{\text {nd }}$ ed. Oxford, Clarendon Press, 1975.

Corresponding author:

Masayuki Kobayashi

Okayama University of Science

Major in Mathematical and Environmental System Science

Graduate School of Informatics

1-1, Ridaicho, kita-ku Okayama City

Okayama, 700-0005

JAPAN

Telephone number: +81-084-934-0857

E-mail: chiroptera.com.ana.9891@gmail.com

Received: 27-10-2017

Accepted: 06-11- 2017 